\title{
Flow Microcalorimetric Measurements of the Antibacterial Activity of the Homologous Series $m$-Alkoxyphenols and p-Hydroxybenzoates on Escherichia coli
}

\author{
P.L.O. Volpe \\ Departamento de Físico-Química, Instituto de Química, UNICAMP, C.P. 6154, \\ 13083-970, Campinas - SP, Brazil
}

Received: May 13, 1996; March 25, 1997

\begin{abstract}
A atividade antibacteriana dos membros de duas séries homólogas ( $m$-alcoxifenóis e $p$-hidroxibenzoatos de alquila) foi estudada in vitro sobre a respiração da Escherichia coli usando microcalorimetria de fluxo. Os resultados para ambas as séries mostraram uma relação linear entre $\log ($ dose $)$ e a resposta calorimétrica $(\mathrm{RC})$. Análise dos dados permitiu a identificação de contribuições de bioatividade concernente a estrutura matriz (a molécula menos os grupos $n-\mathrm{CH}_{2}$ presentes na cadeia lateral) e a grupos lipofílicos, $\mathrm{CH}_{2}$.
\end{abstract}

Antibacterial activity of two homologous series ( $m$-alkoxyphenols and $p$-hydroxybenzoates) was studied in vitro by the respiration of Escherichia coli using flow microcalorimetry. Results for both series showed a linear relationship between $\log (\operatorname{dose})$ and the calorimetric response (CR). Analysis of the data allowed the identification of contributions for the derived bioactivity from the parent structures (the molecule minus $n-\mathrm{CH}_{2}$ groups present in the side-chain) and the lipophilic groups, $\mathrm{CH}_{2}$.

Keywords: biological microcalorimetry, calorimetric response, homologous series

\section{Introduction}

The $m$-alkoxyphenols and $p$-hydroxybenzoates are recognized antibacterials. The alkyl $p$-hydroxybenzoates (parabens) are widely used as preservatives in cosmetic formulations, pharmaceuticals and foods ${ }^{1}$. The antibacterial activities of the $m$-alkoxyphenols have been determined against both Salmonella typhosa (Gram-negative) and Mycobacterium pyogenes var.aureus (Gram-positive) ${ }^{2}$. The activity was shown to depend upon the test organism used. The activity against Gram-negative bacteria increased as the hydrophobic chain length increased. The 'Hansch' correlation ${ }^{3}$ proposes that biological activity is determined by lipophilicity and by the solubility limits in aqueous compartments. Phenols are cytoplasmic poisons $^{4,5,6}$ and hence their lipid solubilities will determine, to a large extent, their ability to cross the cell membrane. It has also been demonstrated that cell walls and cell membranes are damaged by phenols ${ }^{7,8,9}$.
As an alternative to the classical methods for determination of a drugs biological activity, microcalorimetry has been proposed as a general, non-destructive, high sensitivity technique which is in principle, capable of investigating any process or reaction ${ }^{10}$. This generalization, which in some cases may be perceived as a limitation (since all chemical and physical processes give rise to changes in enthalpy), may also be seen as an advantage. This is because it may be useful to have available a technique which, for complex heterogeneous systems, is universally applicable. Moreover as all biological systems have a "built-in" specificity conferred upon them through the enzymatic processes which collectively sum to the overall metabolism, then the application of microcalorimetry may offer insights into metabolism through the observation of the thermal consequences of that metabolism.

The isothermal power-leak flow microcalorimeter shown in Fig. 1 is most commonly used for these studies. It contains two mixing vessels or two flow-through vessels. When the later is used, the reaction mixture, e.g., microor- 


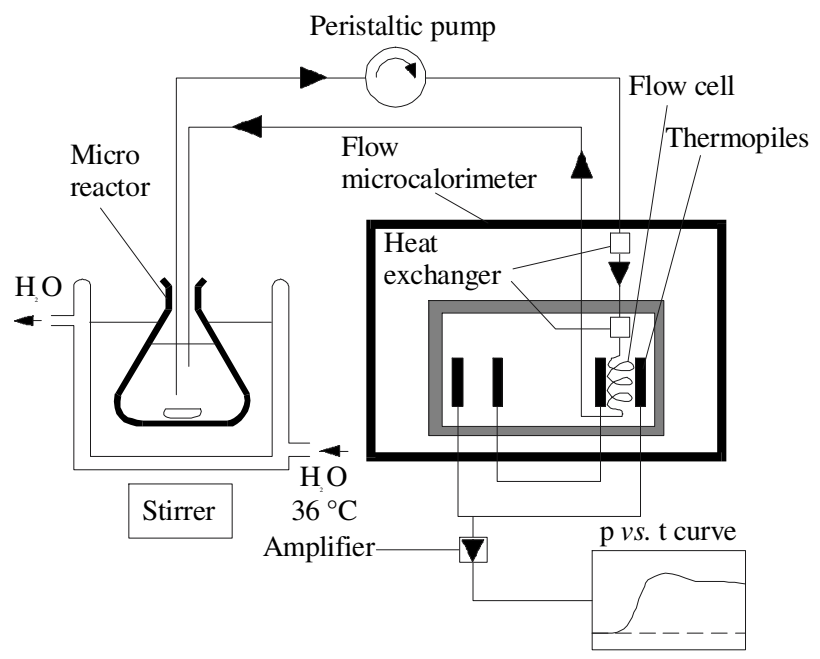

Figure 1. Diagram of the isothermal differential microcalorimeter.

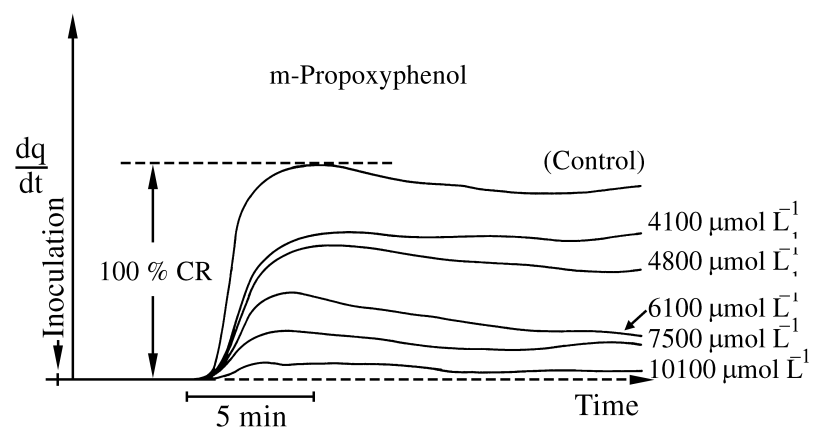

Figure 2. Calorimeter response-t curves obtained for respiration of $E$. coli. Control curve represents the response of bacterial cells alone in glucose buffer. Other curves represents the same process with different concentrations of $m$-propoxyphenol.

ganism plus drug is, pumped through it by a peristaltic pump from a reaction vessel outside the calorimeter, and returned to the reaction vessel, to form a closed loop system. The instrument measures the power generation by the reaction process within the flow-through vessel, relative to power changes in the empty flow-through vessel. The power output is amplified and recorded as a calorimeter response or potency $\mathrm{p}$-t curve

The output of the microcalorimeter (dq/dt $v s . t$; a response-time curve) provides a continuous record of the progress and process of metabolism which, in contrast to many classical procedures, responds to the metabolic activity of only the active microbes present and thus displays details of the dynamic and complex process of metabolism. Biological microcalorimetry, has been used as a modern method for the determination of biological response, in substituiton for the classical methods such as turbidimetry and respirometry ${ }^{11,12}$.

The advantages of flow microcalorimeters for cell-drug studies are: 1. Because of its sensitivity and the fact that the effect of drug(s) on the whole metabolism of the organism may be examined, microcalorimetry may reveal more and also new detail of microorganism-drug interactions than ex-

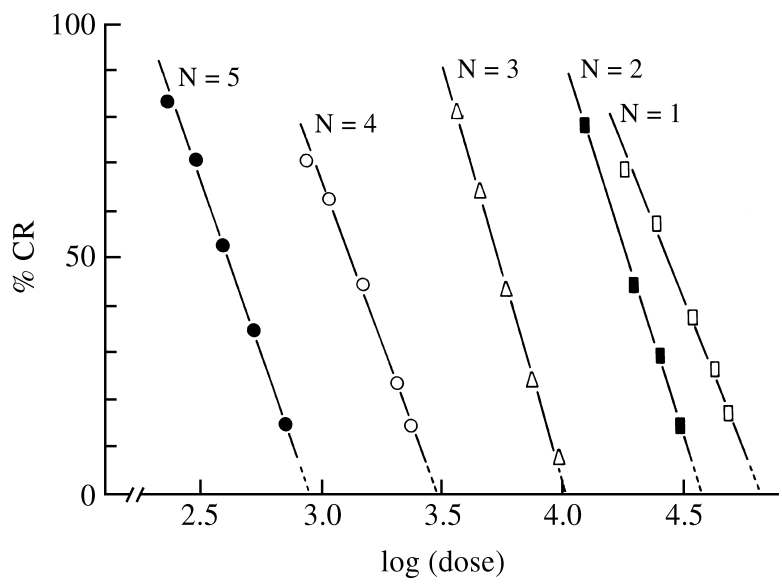

Figure 3. CR vs. Log (dose) for $m$-alkoxyphenols.

tand methods can, especially those which use a specific reaction properly for analysis; 2 . The calorimetric method requires only an observable difference between the calorimetric response (CR) in the treated and untreated (control) incubations, and unlike many other procedures does not require a transparent solution; 3 . The system can be automated. This is of particular relevance for industrial and clinical applications; 4 . The action of antimicrobial drugs can be studied in real time conveniently by means of the response-time curve; 5. The mechanism of the drug action is immaterial: (both antibacterial and antifungal drugs can be examined); 6 . The flow system is more akin to the in vitro state than are, for example, the systems used in diffusion assays; 7 . The flow systems represent the effect of drugs on the total metabolism of the microorganisms. This again more closely approximates the in vitro states than do techniques which measure a single parameter of cell metabolism for analytical purposes.

The disadvantages of the flow microcalorimeters include the following: 1. Microcalorimeters are not sufficiently sensitive to measure the response output from cell concentrations in the range within $10^{2}-10^{3} \mathrm{~mL}^{-1}$. The present detection limit is ca. $10^{4}-10^{5}$ cells $\mathrm{mL}^{-1} ; 2$. Care has to be taken to avoid the presence of gas bubbles or the clumping of cells in the flow lines and microcalorimetric vessels; 3 . Some difficulties, especially with respiring cultures with high cell density, arise because of the time taken for transfer from the reaction vessels to calorimeter, during which a substrate of the medium, often oxygen, can have its concentration changed sufficiently in the metabolic conditions in the calorimeter to be different from those in the reaction vessel. This capacity of the flow microcalorimeter to follow the details of metabolism has, naturally, been extended to microorganism identification ${ }^{10}$, to drug-cell interactions ${ }^{13}$ and bioassay ${ }^{14}$, and, in rather less detail, for the studies of modes of action of drugs upon sensitive microbes ${ }^{10}$.

Any substance that can modify the metabolic process involved in cell growth and/or respiration will, of course, 
Table 1. Values of CR, $\log (\operatorname{dose}), \log (\operatorname{dose})_{\max }$ and linear least square analysis data for the interaction of $m$-alkoxyphenols with $E$. coli.

\begin{tabular}{|c|c|c|c|c|c|}
\hline Compounds & $\begin{array}{c}\text { Dose } \\
\left(\mu \mathrm{m} \mathrm{mol} \mathrm{L}{ }^{-1}\right) \\
\end{array}$ & $\log ($ dose $)$ & $\mathrm{CR}$ & $\begin{array}{l}\text { Correlation } \\
\text { Coefficient } \\
\end{array}$ & $\begin{array}{c}\mathrm{CR}=0 \\
\log (\text { dose })_{\text {max }}\end{array}$ \\
\hline \multirow[t]{5}{*}{$\mathrm{N}=1$} & 49700 & 4.70 & 18 & & \\
\hline & 43600 & 4.64 & 27 & & \\
\hline & 36400 & 4.56 & 38 & & \\
\hline & 26100 & 4.42 & 58 & & \\
\hline & 19500 & 4.29 & 69 & -0.9956 & 4.83 \\
\hline \multirow[t]{4}{*}{$\mathrm{N}=2$} & 32200 & 4.51 & 15 & & \\
\hline & 26600 & 4.43 & 30 & & \\
\hline & 21100 & 4.32 & 45 & & \\
\hline & 13700 & 4.14 & 79 & -0.9612 & 4.58 \\
\hline \multirow[t]{5}{*}{$\mathrm{N}=3$} & 10100 & 4.00 & 8 & & \\
\hline & 7500 & 3.88 & 24 & & \\
\hline & 6100 & 3.79 & 43 & & \\
\hline & 4800 & 3.68 & 64 & & \\
\hline & 4100 & 3.61 & 71 & -0.9963 & 4.03 \\
\hline \multirow[t]{5}{*}{$\mathrm{N}=4$} & 2420 & 3.38 & 15 & & \\
\hline & 2150 & 3.33 & 24 & & \\
\hline & 1570 & 3.20 & 45 & & \\
\hline & 1180 & 3.07 & 63 & & \\
\hline & 950 & 2.98 & 71 & -0.9965 & 3.48 \\
\hline \multirow[t]{5}{*}{$\mathrm{N}=5$} & 740 & 2.87 & 15 & & \\
\hline & 550 & 2.74 & 35 & & \\
\hline & 420 & 2.62 & 53 & & \\
\hline & 330 & 2.52 & 71 & & \\
\hline & 260 & 2.41 & 83 & -0.9981 & 2.96 \\
\hline
\end{tabular}

$$
\begin{aligned}
& \text { Compounds: } \\
& N=1 m \text {-methoxyphenol } \\
& \mathrm{N}=2 m \text {-ethoxyphenol } \\
& \mathrm{N}=3 m \text {-propoxyphenol } \\
& \mathrm{N}=4 m \text {-butoxyphenol } \\
& \mathrm{N}=5 m \text {-pentoxyphenol }
\end{aligned}
$$

change the response-t curve obtained from the calorimeter and so it becomes possible to study by a direct method, the interaction between metabolic modifiers and biological cells in both a qualitative and a quantitative way. The quantitative investigation of drug bioassay results in conventional linear $\log (\mathrm{dose})$-response lines.

In this work, we studied the in vitro antibacterial activity of the homologous series of $m$-alkoxyphenols and $p$-hydroxybenzoates by the respiration of Escherichia coli, using a flow microcalorimetric technique. It was also intended to verify if CR can be partitioned into contributions of

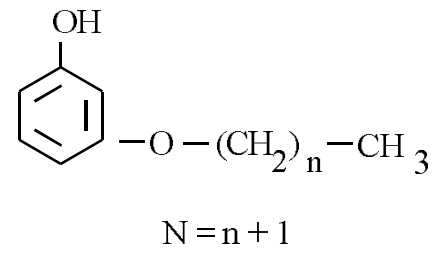

the lipophilic and hydrophilic parts of the molecule $\left(\mathrm{CH}_{2}\right.$ groups and parent structure, respectively). The designation of lipophilic and hydrophilic subunits are identical to those used in the thermodynamic analysis of the partition of these compounds between water and non-aqueous solvents using the Collander equation ${ }^{15}$.

\section{Experimental}

The methoxy and ethoxy derivatives of resorcinol were purchased from Eastman Kodak Co. Ltd. and were repeatedly distilled under vacuum before use. The other resorci- 


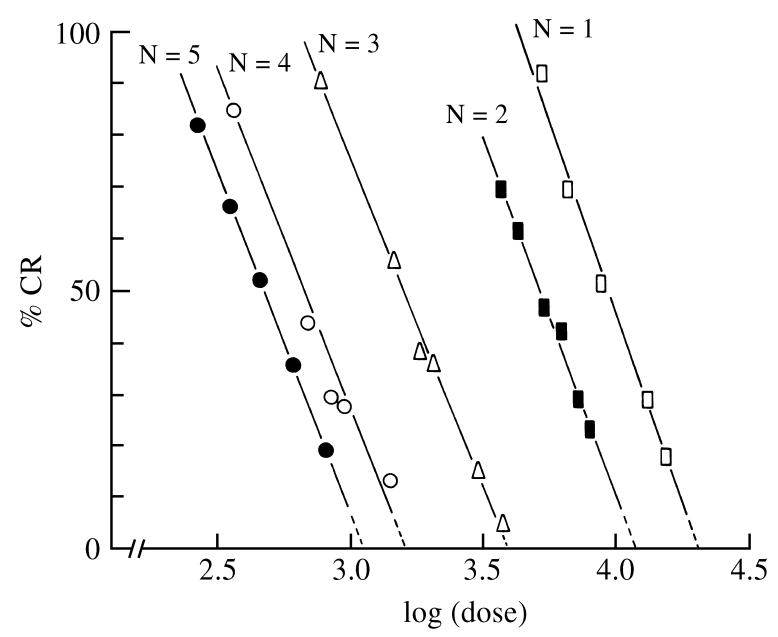

Figure 4. CR vs. $\log$ (dose) for $p$-hydroxybenzoates.

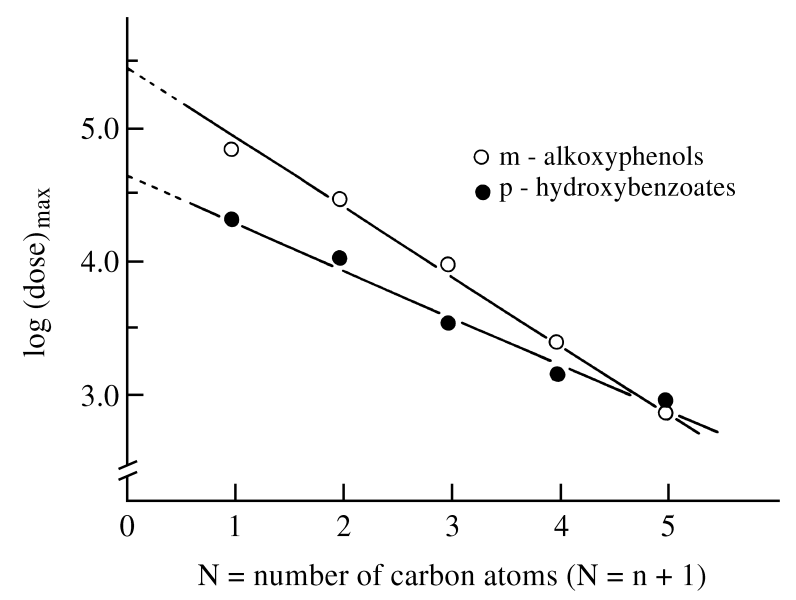

Figure 5. Effect of $\mathrm{CH}_{2}$ groups on $\log$ (dose) $)_{\max }$ values for $m$-alkoxyphenols and $p$-hydroxybenzoates.

nol monoalkyl ethers were prepared by dissolving equimolar amounts of resorcinol and alkyl bromide in the appropriate alcohol followed by gentle boiling under reflux. The theoretical amount of a $25 \%$ aqueous potassium hydroxide solution was added drop by drop during $3 \mathrm{~h}$ followed by boiling under reflux for a further $2 \mathrm{~h}$. Small quantities of diethers were formed in these reactions, particularly with the higher members of the series for which prolonged reaction times were necessary. The reaction mixture was allowed to cool, poured onto ice, acidified and extracted with ether. Excess resorcinol was removed by repeated washing with water and the monoalkyl ethers extracted into potassium hydroxyde solution. Acidification of the alkaline solution followed by ether extraction yielded the alkyl ethers which were distilled several times under reduced pressure $(1.5 \mathrm{mmHg})$.

All the monoethers were assayed for purity by GLC, on a Perkin-Elmer F33 Gas Chromatograph fitted with a $1 \mathrm{~m}$ column containing 3\% SE 30 on Chromosorb W, 80-100 mesh (oven temperature $110^{\circ} \mathrm{C}$; injector/detector temperature $150{ }^{\circ} \mathrm{C}$; carrier gas $\mathrm{N}_{2}\left(30 \mathrm{~mL} \mathrm{~min}{ }^{-1}\right)$, mixture of hydrogen $\left(30 \mathrm{~mL} \mathrm{~min}^{-1}\right)$ and air $\left(300 \mathrm{~mL} \mathrm{~min}^{-1}\right)$ used for flame ionization detector). NMR spectroscopy was used to confirm the structures of the compounds and to detect impurities, if present.

$p$-Hydroxybenzoates were the generous gift of NIPA chemicals and were certified as $99.9 \%$ pure on delivery. They were used without further treatment.

Escherichia coli NCTC 10418 was grown in $250 \mathrm{~mL}$ flasks containing $40 \mathrm{~mL}$ of medium of composition $\left(\mathrm{g} \mathrm{L}^{-1}\right)$ : glucose, 40; $\left(\mathrm{NH}_{4}\right)_{2} \mathrm{SO}_{4}, 2.0 ; \mathrm{NaH}_{2} \mathrm{PO}_{4}-2 \mathrm{H}_{2} \mathrm{O}, 7.8$; $\mathrm{K}_{2} \mathrm{HPO}_{4}, 8.4 ; \mathrm{MgCl}_{2}, 0.13 ; \mathrm{CaCO}_{3}, 0.003 ; \mathrm{FeSO}_{4} .7 \mathrm{H}_{2} \mathrm{O}$, $0.007 ; \mathrm{MnCl}_{2} .4 \mathrm{H}_{2} \mathrm{O}, 0.001 ; \mathrm{ZnSO}_{4}, 0.0005 ; \mathrm{CaCl}_{2} .6 \mathrm{H}_{2} \mathrm{O}$, $0.0002 ; \mathrm{CuCl}_{2} .2 \mathrm{H}_{2} \mathrm{O}, 0.0003 ; \mathrm{H}_{3} \mathrm{BO}_{3}, 0.0001$; $\mathrm{Na}_{2} \mathrm{MoO}_{4} .2 \mathrm{H}_{2} \mathrm{O}, 0.0003$; final $\mathrm{pH}$ 7.0. Forty flasks were inoculated with $0.8 \mathrm{~mL}$ of an overnight culture and incubated at $37{ }^{\circ} \mathrm{C}$ on a rotary shaker $(220 \mathrm{rpm}$ : Gallenkamp, U.K.). Growth was followed by optical density (EEL colorimeter) and $6 \mathrm{~h}$ after incubation, at an optical density equivalent to $1.2 \mathrm{~g}$ dry weight of cells/litre, the cells were pooled, centrifuged, washed twice in 1/4 strength Ringer's solution containing $10 \% \mathrm{w} / \mathrm{w}$ of dimethylsulfoxide (DMSO) at $4 \mathrm{~g}$ dry weight of cells $\mathrm{L}^{-1}$. After the last centrifugation, the cells were resuspended in Ringer's solution containing $10 \%$ of DMSO and conditioned in $2 \mathrm{~mL}$ polypropylene ampoules. The ampoules were inserted into a thin perfurated Styrofoam plate which was the lid of an aluminum container for liquid nitrogen. The Styrofoam plate was mantained at a height of $8 \mathrm{~cm}$ above the nitrogen level and when the temperature in the control ampoule reached $-80{ }^{\circ} \mathrm{C}$ (measured with an alcohol thermometer), the ampoules were liberated for immersion in liquid nitrogen and stored in a cryogenic cylinder ${ }^{16}$. The viable count was done periodically, giving $1.3 \times 10^{10}$ cells $\mathrm{mL}^{-1}$. Cells stored for 6 months were recovered with $95 \%$ viability.

The antibacterial activity of the compounds of the two homologous series were determined by using an isothermal differential microcalorimeter (LKB-10700) at $36^{\circ} \mathrm{C}$, fitted out with a flow-through cell. The microcalorimeter scheme is shown in Fig. 1. The media is pumped into the flow-through cell $\left(35 \mathrm{~mL} \mathrm{~h}^{-1}\right)$ with the help of a LKB-2132 peristaltic pump.<smiles>Oc1cccc(O)c1</smiles><smiles>O=C(O)c1ccc(O)cc1</smiles>

(I)

(II)

Scheme 1. 
Table 2. Values of $\mathrm{CR}, \log (\mathrm{dose}), \log (\mathrm{dose})_{\max }$ and linear least square analysis data for the interaction of $p$-hydroxybenzoates with $E$. coli.

\begin{tabular}{|c|c|c|c|c|c|}
\hline Compounds & $\begin{array}{c}\text { Dose } \\
\left(\mu \mathrm{mol} \mathrm{L}^{-1}\right)\end{array}$ & $\log ($ dose $)$ & $\mathrm{CR}$ & $\begin{array}{c}\text { Correlation Coeffici- } \\
\text { ent }\end{array}$ & $\begin{array}{c}\mathrm{CR}=0 \\
\log (\text { dose })_{\max }\end{array}$ \\
\hline \multirow{5}{*}{$N=1$} & 15800 & 4.20 & 19 & & \\
\hline & 13700 & 4.14 & 30 & & \\
\hline & 9300 & 3.97 & 52 & & \\
\hline & 7000 & 3.85 & 70 & & \\
\hline & 4700 & 3.67 & 93 & -0.9981 & 4.32 \\
\hline \multirow[t]{6}{*}{$N=2$} & 8400 & 3.92 & 24 & & \\
\hline & 7500 & 3.88 & 30 & & \\
\hline & 6600 & 3.82 & 43 & & \\
\hline & 5700 & 3.76 & 47 & & \\
\hline & 4700 & 3.67 & 62 & & \\
\hline & 4000 & 3.60 & 70 & -0.9916 & 4.08 \\
\hline \multirow[t]{6}{*}{$N=3$} & 3800 & 3.58 & 5,2 & & \\
\hline & 3100 & 3.49 & 15 & & \\
\hline & 2200 & 3.34 & 36 & & \\
\hline & 1900 & 3.28 & 38 & & \\
\hline & 1600 & 3.20 & 56 & & \\
\hline & 870 & 2.94 & 91 & -0.9957 & 3.60 \\
\hline \multirow[t]{5}{*}{$\mathrm{N}=4$} & 1450 & 3.16 & 14 & & \\
\hline & 970 & 2.99 & 28 & & \\
\hline & 870 & 2.94 & 30 & & \\
\hline & 720 & 2.86 & 44 & & \\
\hline & 380 & 2.60 & 85 & -0.9831 & 3.21 \\
\hline \multirow[t]{5}{*}{$\mathrm{N}=5$} & 810 & 2.91 & 19 & & \\
\hline & 630 & 2.80 & 36 & & \\
\hline & 480 & 2.68 & 52 & & \\
\hline & 380 & 2.58 & 66 & & \\
\hline & 290 & 2.46 & 82 & -0.9996 & 3.06 \\
\hline
\end{tabular}

Compounds:

$\mathrm{N}=1$ methyl $p$-hydroxybenzoate

$\mathrm{N}=2$ ethyl $p$-hydroxybenzoate

$\mathrm{N}=3$ 1-propyl $p$-hydroxybenzoate

$\mathrm{N}=4$ 1-butyl $p$-hydroxybenzoate

$\mathrm{N}=5$ 1-pentyl $p$-hydroxybenzoate

The heat output from the respiration metabolism of $E$. coli is detected by the pair of thermopiles connected around the flow-through cell ${ }^{17}$. The composition of the culture media used for the respiration of E. coli was $\left(\mathrm{g} \mathrm{L}^{-1}\right)$ : glucose, $0.5 ; \mathrm{K}_{2} \mathrm{HPO}_{4}, 8.75 ; \mathrm{K}_{2} \mathrm{PO}_{4}, 3.75 ; \mathrm{pH}=7$. Without the addition of the bioactive compounds, this media was defined as a control preparation. The inoculation of microorganisms

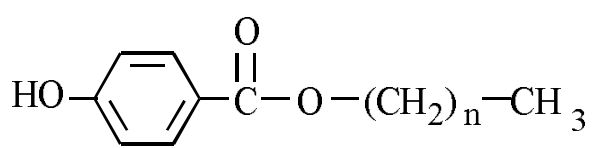

$$
\mathrm{N}=\mathbf{n}+\mathbf{1}
$$

(500 $\mu \mathrm{L}$ of the cell suspension) was always done immediately after thawing the ampoule for $3 \mathrm{~min}$ in a water bath at $36{ }^{\circ} \mathrm{C}$, followed by agitation of $20 \mathrm{~s}$.

\section{Results and Discussion}

Figure 2 shows the thermograms for the respiration of E. coli. The control curve is the thermogram of E. coli in 
this process, without the addition of any drug, obtained by pumping the aerated bacterial suspension through the flowthrough cell by means of a peristaltic pump, Fig. 1 .

The other curves of Fig. 2 show the effect of the increasing concentration of $m$-propoxyphenol on the respiration process. In biological microcalorimetry, the calorimetric response, $\mathrm{CR}$, is defined comparing the maximum height of the thermogram in each concentration of the drug with the maximum height of the control curve $(100 \% \mathrm{CR})^{10}$. Also, the concentration of the drug is defined as dose and the value of $\log$ (dose) when CR $=0$ is denominated $\log (\text { dose })_{\max }$. It is obtained by extrapolation of the curves CR vs. log (dose) and represents the logarithm of the concentration of the drug which if added to the cell media should not produce a response in the calorimeter. In this work the values of $\log$ (dose) max $_{\text {ax }}$ for each compound were obtained by extrapolation from Figs. 3 and 4.

From the microcalorimetric study of the effect of the bioactive compounds, $m$-alkoxyphenols and $p$-hydroxybenzoates, on the respiration of $E$. coli, it was possible to demonstrate the existence of the linear correlation between $\log$ (dose) and the calorimeter response. Figures 3 and 4 show the calorimetric data obtained from the thermograms of interaction of the homologous series of $m$-alkoxyphenols and $p$-hydroxybenzoates with $E$. coli cells, using the CR value calculated as was shown in Fig. 2.

Tables 1 and 2 show the calorimetric response data of the compounds of the two homologous series together with the correlation coefficient, obtained from Figs. 3 and 4.

A graph of $\log (\text { dose })_{\max } v s$. number of $-\mathrm{CH}_{2}$ groups present in the side-chain gave a correlation coefficient of -0.9931 and -0.9877 , intercepts of 5.428 and 4.671 and slopes of -0.484 and -0.339 for the homologous series of $m$-alkoxyphenols and $p$-hydroxybenzoates, respectively, Fig. 5.

For each homologous series of the compounds studied here, we defined a "parent" structure, m-alkoxyphenols (I) and p-hydroxybenzoates (II) (Scheme 1).

The value of the intercepts in concentration terms, $268,000 \mu \mathrm{M}$ and $47,000 \mu \mathrm{M}$ are then the concentrations (hypothetical) of the parent structure for the series $m$-alkoxyphenol and $p$-hydroxybenzoate, respectively.

It is notable from Fig. 5, but perhaps not surprising, that the parent structure of the phenol is less bioactive than is the parent structure of the $p$-hydroxybenzoate. Moreover, the contribution per $\mathrm{CH}_{2}$ group to the variation in bioactivity is different for the two homologous series but, as the hydrophobicity of these compounds increases, the bioactivity gets closer, being practically the same for the five carbon chains.

The value of $\log (\text { dose })_{\max }$ allows the evaluation of the relative antibacterial activity of the compounds, since all the bioactivities are related to the same reproductive pattern, that is, complete inhibition of heat production in the microcalorimeter $(\mathrm{CR}=0)$. For the studied antibacterial compounds the additivity principle was observed as well as that $\mathrm{CR}$ can be partitioned into a bioactivity contribution of the parent structure plus the number of $\mathrm{CH}_{2}$ groups present in the side chain.

The CR data obtained through flow microcalorimetry shows that there is great potential for microcalorimetric measurements in basic sciences, medicine, pharmacology and toxicology. The future for calorimetry in this field is bright, now that the techniques have been established and, with the development of improved instrumentation for monitoring thermal and other supplementary properties of systems, it will be possible to make even more detailed studies of cellular systems.

\section{Acknowledgements}

The author is grateful to Professor Anthony E. Beezer for the helpful discussions, to NIPA Laboratories Ltd for the gift of samples of $p$-hydroxybenzoates and to Dr. Silvia Eguchi, of the Fundação Tropical de Pesquisa Tecnologica - FTPT, Campinas, for help in the microbiological preparations.

\section{References}

1. Dimicky, M. e Huhtanen, C.N., Antimicrob. Agents Chemother., 1979, 15, 798.

2. Klarmann, E., Gatyas, L.W., Shternov, V.A., J. Am. Chem. Soc., 1931, 53, 3397.

3. Hansch, C., Fujita, T., J. Am. Chem. Soc., 1964, 86, 1616.

4. Roberts, M.H., Rahm, O., J. Bacteriol., 1946, 52, 639.

5. Judis, J. I., J. Pharm. Sci., 1962, 51, 261.

6. Hedgecock, L.W., Antimicrobial Agents, Lea and Febiger, Philadelphia, 1966.

7. Gale, E.F., Taylor, E.S., J. Gen. Microbiol, 1947, 1, 77.

8. Maurice, P., Proc. Soc. Appl. Bacteriol., 1952, 15, 144.

9. Tomcsik, J., Proc. Soc. Exp. Biol. Med., 1995, 89, 459.

10. Beezer, A.E., (ed). Biological Microcalorimetry. Academic Press, London, 1980.

11. Volpe, P.L.O., Química Nova, 1987, 10, 122.

12. Volpe, P.L.O., Química Nova, 1988, 11, 435.

13. Beezer, A.E., Volpe, P.L.O., Miles, R.J., e Hunter, W.H., J. Chem. Soc., Faraday Trans I, 1986, 82, 2929.

14. Beezer, A.E., Volpe, P.L.O., Gooch, C.A. e Hunter, W.H., Anal. Proc., 1986, 23, 399.

15. Beezer, A.E., Gooch, C.A., Hunter, W.H. e Volpe, P.L.O., J. Pharm. Pharmacol, 1987, 39, 774.

16. Kirsop, B.E., Snell, J.J., Maintenance of Microorganisms, Academic Press, New York, 1984.

17. Volpe, P.L.O., Química Nova, 1993, 16, 49. 